\title{
DEVLETLER HUSUSİ HUKUKUNDA KANUNA KARŞI HILE
}

\author{
Dofent Dr. Osman Fazal BERKI
}

\section{$\$ I$ - Kanuna karşt bile mefbumu ve misalleri:}

Devletler hususi hukuku, arsıulusal bir unsuru «Elément international» ihtiva eden hukuki bir münasebete tatbik edilecek kanunu gösterir.

Devletler hususi hukukunda şahısların iradesi doğrudan doğruya veya dolayısiyle kanun ihtilâflarının «Yasaların çatışması=Conflits de lois» halinde mühim bir rol oynar.

Meselâ: Akitlerin şekilleri mevzuubahis olunca alâkadarlar, ülkesinde bulunduklanı Devlet kanununun kabul eylemiş olduğu şekilleri dahilinde hareket edebilirler. lkametgâh, mahkemelerin salâhiyeti üzerinde mühim tesir icra eder. Menkuller, bulundukları mahal kanununa «Lex Rei Sitae» tâbidirler, ve bunlar bir memleketten diğer memlekete nakledilebilirler.

Su haller bize, birtakım suiistimallerin ortaya çıabileceğini açıķa göstermektedir.

Acaba, hukuki bir münasebette taraflar, bir ihtilâf kaidesine istinadederek, hile «Fraude» ile başka bir kanunun tatbik edilmesini temin edebilirler mi? Yani alâkalılar, normal olarak kendilerine tatbiki lâzum gelen kanunun mecburi hükümlerini bertaraf etmek maksadiyle bazi hilelere müracaat ederlerse hileli muameleri hüküm ifade eder mi?

Kanuna karşı hile: «Fraude à la loi» yahut «Fraude contraire à la loi» I $\left[^{1}\right]$ adını alan bu mesele şu misallerile aydınlatılabilir:

Îtalyada boşanma müessesesinin dinî mülâhazalarla yasak edildiği malûmdur. Italyan tâbiiyetinde olan karı koca sırf boşanabilmek için Türk tâbiiyetini iktisabediyor, ve Türk olmak sıfatiyle boşanma dâvası açıyorlar. Boşanmaya hükmediliyor; bu boşanma kararının Italyada hukuki bir kiymeti olacak mi? yani bu karar Italyada tanınacak midır?

[1] Bu term hakkinda bak: Dr. F. Halłki Saymen, hileyi seriye, hukuki bilgiler mecmuasi 1I. Kanưn 1941, Sayi 3-135 S. 7375 ve M. 
Son zamanlara kadar Fransada tahkim şartı uclause compromissoire» ne âdi mukavelelerde ne de ticari mukavelelerde kabul edilmemiştir. Bahrî Sigorta mukaveleleri buna istisna teşkil etmekte idi adi mukavelelerde bu şart şimdiye kadar tanınmamıştır.

Tahkim şartı Ingiltere ve Almanyada her türlü mukaveleler için muteber addedilmektedir. Fransa da mahkeme içtihatltrı, mukavelenin inikatettiği memleket mevzuatı kabul eylediği takdirde tahkim şartını koymak için, Fransız kanununun hükmüinden kurtulmak maksadiyle Ingiltere veya Almanyaya giderek bu şarı mukavelelerine koyarlarsa. bu, Fransada hüküm ifade edecek midir?

Mahkeme içtihatları yeni bir mefhum olan karuna karşı hile mefhumunu tarif etmeksizin ona baş vurularak yapılan muameleleri iptal eylemektedir.

\section{$\$ 2$ - Doktrinde kanuna karşı bile:}

Kanuna karşı hile hakkında Doktrini üçe ayırabiliriz:

A - Kanuna karşı hileyi reddeden Doktrin;

B - Kanuna karşı hileyi kısmen kabul eden Doktrin;

C - Kanuna karşı hileyi kabul eden Doktrin;

A - Kanuna karşı hileyi reddeden Doktrin:

Bazı müellifler, kanuna karşı hilenin Devletler hususi hukukunda yeri olmadtğı fikrini ileri sürmektedirler. Bu müelliflerin ileri sürdükleri deliller şöylece hulâsa edilebilir:

1 - Bir kimse bir kanundan istifade etmek isterse, hukukan buna salâhiyeti olup olmadığını araştırmaktan başka çare yaktur. Yoksa onun bu kanundan istifadesini temin eden vaziyeti ihdasta nasıl bir maksat taşımıs olduğunu aramaya hâkimin salâhiyeti yoktur; hâkim, bunu araştırmaya asla mezun değildir ve olamaz.

2 - Hâkimin, hile yapmak suretiyle kanun hükmünïn ihlâl edilmesi dolayısiyle muteber olan bir muameleyi nazara almamasi takdirinde bu muamelenin diğer hüiümleri baki kalacağından hilenin nazara alınması içinden çıkılmaz müşkilâtın meydana gelmesine sebedolur.

Meselâ: İtalyanların Türkiyede boşanabilmek için türk tâbiiyetini iktisabetmeleri halinde boşanma hükü̈msüz addedilse bile, tâbiiyet muteber kalacaktır. Bu da, biraz evvel bahis mevzuu olan müşkülâtı doğuracaktır.

3 - Kanuna katşı hile nazariyeși hukukun inkişafına, tekâmülüne, engel olur. 


\section{B - Kanuna katşı hileyi kısmen kabul eden Doktrin:}

Hile mefhumuna Devletler hususi hukukunda yer vermiyen doktrinin yanı başında diğer bir doktrin yer almuş bulunmaktadır. Bu Doktrine göre hile, ancak mukavelelet ve bunlatın şekilleri hakknda bahis mevzuu olabilir.

Bu Doktrin diğer sahalarda tâbiiyet değiştirme ihtimallerinde hile mefhumunu reddetmektedir.

Bu fikri ileri süren müellif Devletler hususi hukukunda hukuki sistem «Systéme juridique» adınadki nazariyesiyle şöhret kazanan Frans.z hukukçularnndan P. Arminjon dur $\left[{ }^{2}\right]$.

\section{C - Hileyi kabul eden Doktrin:}

Bir kısım müellifler hileye Devletler huhusi hukukunda yer verirler. Bu müelliflere göre böyle bir usule lüzum vardır. Cünkiu, vïcuda getirilen her hangi bir vaziyetle bir kanunun emredici hükümlerine muhalefet edildiği takdirde bu Âmir hükümlerin nüfuzunu temin için vaziyetin hileli olup olmadı̆ınt araștırmaktan, ve hileli olduğu, yani emredici hükümlerden kaçınmak maksadiyłe yeni bir vaziyet vücuda getirilmiş bulunduğu görülünce o vaziyetin neticesi olarak diğer bir kanundan istifade imkânını kaldırmaktan başka çare yoktur.

Burada iki hali biribirinden dikkatle ayırmak lâzımdır:

A - Eğer misalimizdeki Italyan tâbiiyetini haiz olan şahsın, Türk tâbiiyetini hüsnüniyetle, yani hile kullanmıyarak iktisabetmiş ise bunun elde ettiği boşanma hükmü muteber olmak lâzım gelir. Bu şahıs artık normal şekilde Türk kanunlarına tâbi olacak ve hattâ eski vatanı olan Italyada ahvali şahsiyesine «Statut Personnel» Millî Kanunu «Lex Patriae» olan Türk kanunu tatbik edilecektir.

B - Bu Italyan Türk tâbiiyetini normal şekilde değil, ve fakat hilelì olarak iktisabetmiş ise, elde ettiği boşanma hükmü muteber olmamak icabeder. Zira, tâbiiyet değiştirme samimî olmamış, kanunun âmir hükümierinden kaçmak maksadiyle hileli bir şekilde vukubulmuştur.

\$3-Kanuna karş bilenin tatbiki sartlort:

Kanuna karşı hilenin tatbik mevkiine konulabilmesi için iki şartın tahakkuku lâzımdır:

[1] Arminjon, Pubicis de droit international priure, 2 lédision nos 99 à 124. Hukuki sistem, isctionai hayatlarmon esasis unsurlarmı tanzim eden huikuki bir kaide ife ve ekseriya idari ve kazai tesisatla biribirlerine bağlı bulunan bir insan topluluğudur. Şeklinde tarif edilmektedir. Devlet le hukuki sistem arasinda husus ve umum mutlak vandir. 
1 - Hile «fraude»;

2 - Gayri meşru bir netice «résultat illegitime»;

1 - Hile «fraudes:

Kanuna karşı hile bahis mevzuu olabilmek için muamelenin kanunu bertaraf etmek niyetiyle yapıImış olması şarttır. Görülïuyor ki, bu nazariyenin devletlerarast hukukundaki mahiyeti dahili hukukta Roma hukukundan beri meşhur olan ve Fransız hukukunda «action oblique» adiyle anılan «actio pauliapa-action paulienne» yani alacaklilara zarar vermek maksadiyle borçluların normal olmiyan hile ve manavralarından ayrıdır. Bahsetmekte olduğumuz kanuna karşı hile nazariyesi aynı maksa da hizimet etmez. Burada şahıslar, kanuna hile yaptıkları zaman alacaklulardan birine bir zarar iras etmek istemezler. Bunların maksatları işlerine gelmiyen kanunun hükümilerinden kurtulmaktır. Bizi alâkadar eden hile niyettir, «intenion» yani arzu edilen muamelenin yapılmasına engel olan bir kanunun hükümlerini ihlâl etmek arzusudur. Görïlüyor ki, burada mühin olan nokta kanuna riayet etmemek, onun hükümlerinden kaçınmalıtır. Bundan şöyle bir netice çıkar: şayet taraflar kendileri için daha faideli olan ecnebi bir kanunun hâkimiyeti altına girerler, ve fakat bu hususta eski kamundan kaçınmak maksadinı gütmezlerse hile tahakkuk etmemiş olur: Binaenaleyh varılan neticeyi değil, isnat derecesini «degré d, imputabilité» tetkik etmek lâzım gelir. Burada psikolojik unsur «élément psychologique» daha ziyade muiessirdir [ $\left.{ }^{3}\right]$.

Kanunun hükmünü bertaraf etmek psikolojik bir unsurdan ibaret olmasına göre her türlü vasıta ile ispat edilebilir.

\section{2 - Gayri meşru bir netice «résultat illicite»:}

Tarafların, kanunun memnu addettiği bir neticeyi istihsal için yaptıkları muamele hükümsüzdür. Netice fiilen hâsıl olmadığı takdirde kanuni müeyyidelerin tatbikı imkânı var mıdır?

Buna menfi cevap vermek lâzımdır. Tarafların hileli niyetleri kanunun men'eylediği bir neticeye müncer olmadtğı, yani gayri meşru netice tahassul -etmediği takdirde, yapilan muamele hükümsüz addedilemez. İstihsal olunan netice gayri meşru addedilebilmek için müracaat edilen vasıtanın hukuki ve fïlî neticeleri ile, memnu olan netice arasııda bir muadelet «équivalence» bulunmak icabeder.

Meselâ: Türk tâbiiyetinde olan bir sahıs memleketinde askerî bizmetten kurtulmak için ecnebi bir devlet tâbiiyetine geçer ve fakat bu

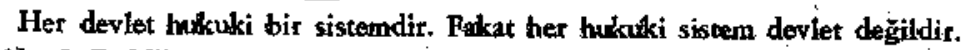

["] J. P. Niboyet, manuel de droit international prike, 2 e. edition P. 579. 
devletin kendisine tahmil eylemiş olduğu askerlik mükellefiyetinden kurtulmak için hiģbir şey yapmazsa bu tâbiiyet değişmesi normal addedilmek lâzım gelir. Ve fakat, bilâkis bu şahıs her iki memlekette fiilî askerlik hizmetinden kurtulacak bir vaziyet ihdas ederse hu.takdirde kanuna karşı hile karşısında bulunuyoruz demektir.

\$ - Kanuna karģ bilenin bukuki mabiyeti:

1 - Kanuna karşı hile ve âmme intizamı:

Acaba kanuna karşı hile âmme intizamına «Ordre pulic» muhalif bir muamele olarak telâkki edilebilit mi?

Malûmindur ki, âmme intizamı, normal şekilde salâhiyettar olan bir ecnebi kanununun «loi étrangère normalement compétente» tatbikına mâni olan bir çaredir. Âmme intizami, istisnai bir mahiyeti haizdir. Devletler hususi hukukunun tatbikına mâni olur. Daha doğru bir tâbirle, âmme intizamu bahis mevzuu olduğu zaman devletler hususi hukukunun muayyen bir kanun ihtilâfına tatbiki imkânsız olur.

Meselâ: bir ecnebi Türkiyede zina mahsulü olan bir çocuğu «enfant adultérin» kendi millì kanununa müsteniden tanımak istese buna Türk âmme intizamı engel olacaktır.

Görülüyor ki, âmme intizamı öyle bir çaredir ki, bu çare sayesinde bir memleket mahkemeleri ecnebi bir kanunun tatbikın bertaraf ediyor.

Şu halde, âmme intizamr ile yukarda tarifini yapı̆ğımı kanuna karşı hile mefhumu arasındaki münasebet neden ibaretcir?

Devletler hususi hukuku müelliflerinden Etienne Bartin kanuna karşı hile mefhumunu, âmme intizamt mefhumuna sokmaktadır $\left[{ }^{4}\right]$.

Bu müellife göre kanuna karşıı hile, âmme intizamına dâhildir. Kanuna karşı hile âmme intizamının bir nevidir. Çünkü, ecnebi bir kanunun tatbikı, yalnız o kanunun hükmünden istifade tarzi, yani hile dolayısiyle de cemiyet için zararlı olabilir. Işte bu takdirde keyfiyetin âmme intizamı ile alâkası vardır. Bartin'e göre yabancı bir kanunun tatbikını temin eden hile âmme intizamını ihlâl eder. Artık ayrıca hileyi derpiş etmeye lüzum yoktur.

Bu müellifin fikrine iştirak zordur. Çünkü, âmme incizamı mefbu+ mu, kanuna hile mefhrumundan tamamiyle ayrıdır. Zira hile, âmme intizamının ihtiva etmediği kasıt unsurunun «élément intentionnel»» mevcudiyetini icabettirir. Hile mevcut olabilmek için içtimai karışıklıktan «trouble social» başka bir de kasıt lâzımdır.

[4] E. Bartin, tandes de droit intemational prine P. 2bS et $S$. 
Sonra kanuna hileyi âmme intizamı mefhumuna sokan Doktrin hâkimin $\mathrm{K}$. nun. «Lex fori» ilham aldı̆̆ telâkkilerden mülhem olmuş bir ecnebi kanununa yapılan hileyi nazarı dikkate almaktadır. Binaenaleyh, bu Doktrin bizi, hâkimin $\mathbf{K}$. nun ilham aldı̆̆ı telâkilerden mülhem olmıyan bir ecnebi kanununa karşı yapılacak hilenin her nevi müeyyideden kurtulması neticesine sevkeder. Çünkü, vaziyet ,dâvanın ikame edildiği mahal $\mathrm{K}$. nun «loi du lieu où l'action a été intentée» âmme intizamını ihlâl etmemektedir.

Netice olarak denilebilir $\mathbf{k i}$, âmme intizamı ile kanuna karşı hile başka başka şeylerdir. Yani hile halinde ecnebi $\mathbf{K}$. nun, mahallî kanunla ihtilâf haline gelmesi ve ona mugayereti bahis mevzuu değildir.

Bu kaideden maksat, yapılan bir hileye karşı tedbir almaktır. But hususi bir çare ister. Bundan dolavıdır $\mathrm{ki}$, bu hile nazariyesine âmme intizamından ayrı olarak yer vermek lâzımdır.

Kanuna karșı hile «Subjectif» vasfiyle, yani kasut unsurunu ihtiva eylemesiyle âmme intizamından ayrılmaktadır.

2 - Muvazaa «Simulation» ve kanuna karşı hile:

Acaba muvazaa «Simulation» ile kanuna karşı hile aynı mânayı mr ifade etmektedir? Bu soruya müspet veya menfi bir cevap verebilmek muvazaanın mahiyetini tebarüz ettirmekle kabil olacağı şüphesidir.

Borçlar kanunumuzun 18 inci maddesinde hükme bağlanan muvazaanın şu şekilde tarif edilmesi mümkündür: Ister bir taraflı, ister iki tarafli olsun hukuki bir muamele zımnında birden ziyade kimselerin hakiki iradeye uymiyan bir beyanda bulunmayı kararlaştırmalarına muvazaa derler $\left[{ }^{s}\right]$.

Taraflar muvazaalı muameleyi hakikatta ya hiç istememişlerdir - ki buna mutlak muvazaa «simulation absolue» derler - veyahut onun başka türlü bir mahiyette olmasınt arzu etmişler - ki buna da nispî muvazaa «simulation relative») adi verilmektedir.

Kanuna karşı hilenin gayesi ise tamamen başkadrr. Filhakika, kanuna karşı hilede taraflar bîr kanunun âmir hükümlerini bertaraf etmek vevahut normal şekilde tatbikt icabeden bir yabanct $K$. nun tatbikınt temin eylemek maksadiyle kanunen caiz ve hakiki arzuyu ifade eden muamelelere baş vurmaktadırlar.

[5] Ahmet Esat Ersebitik, akitlerde muvazaa ve tabikatcaki sekilleri 26/12/942 tarihinde Ankara Dil Tarih ve Coğrafya Falkültesinde verinlen konferans, Adliye Ceridesi 1943, sayi 10.5 .72 . 
Görülïyor ki, kanuna karşı hile ile muvazaa başka başka şeylerdir. Bu iki mefhumun biribixinden tefriki tamamen nazari bir mesele değildir.

Evvelâ: Bu tefrik faidelidir, çünkü, muvazaanın müeyyidesi hiçbir itiraza meydan vermemektedir. Halbuki kanuna karşı hile böyle değildir. uymaz.

Saniyen: Bu iki mefhumun tevlit ettikleri neticeler de biribirine

Muvazaalı muameleler âkit taraflara "parties contractantes» karşı hiçbir hüküm ve netice doğurmadığı gibi, prensip itibariyle üçüncü şahıslar hakkında da bâtıldır. Prensip itibariyle diyoruz. Zira, bunun bazı istisnaları vardir.

Filhakika, Borçlar K. nun 18 inci maddesinin ikinci frkrasına göre tarihî borç ikrazına isnaden alacaktı olan kìmse bunu üçüncü bir şahsa temlik ettiği takdirde asıl borçlu bu üçüncü şahsa karşı muvazaa iddiast dermeyan edemez. Burada temellük eden kimse, hüsnü niyeti sayesinde temlik eden kimse de «mümellik - Cédant» bir alacağa sahip oluyor. Böylece temellük eden kimsenin hüsnüniyeti normal hudutları tecavüz edecek bir şekilde himaye edilmiştir.

Ikinci bir istisnayı da Medenî $K$. nun 687 ve 901 maddeleri teşkil eylemektedir. Bir menkulü muvazaa tariki ile malik diğer bir şahsa devir ve teslim ettiği ve bu şahıs da mezkûr menkulï hüsnï niyetle üçüncü bir şahsa sattı̆̆ takdirde bu iktisap muteberdir.

Muvazaanın hïkmü ve neticeleri bunlardan ibarettir. Halbuki kanuna karşı hile mefhumu tamamen başka : hüküm ve neticeler tevlit etmektedir.

Kanuna karşı hilenin tevlit edeceği hüküm ve neticelerin muvazaanın hüküm ve neticelerinden farklı olduğu, ve bunların nelerden ibaret bulunduğu ilerde vereceğimiz izahattan anlaşılacaktır.

3- Kanuna karşı hile ve hakkın suiistimali:

Kanuna karşı hile ile hakkın suiistimali «abus de droit» arasında bir münasebet var midir? .

Hakkın suiistimali, bir şahsın sahip olduğu bir hakkı kanuni ve sosyal gayesi haricinde kullanarak başkasına zarar iras etmesi demektir.

Filhakika, Medenî Kanunumuzun2 nci maddesinin 2nci fıkrası şöyle bir hükmü muhtevi bulunmaktadır: «Bìr hakkın sırf gayri ızrar eden suiistimalini kanun himaye etmez: 
Hukukumuzda hakkın suiistimali mevzuubahis olabilmek için şu şartların tahakkuku lâzımdır:

a - Bir hakkın vücudu lâzımdır.

b - Istimalden bir zarar meydana gelmelidir.

c - Bu zarar kasdî olmalıdı.

Hakkin suiistimali meselesi strf gayri tzrar eden suistimallete münhasırdır. Binaenaleyh, başka bir şahsın zararını mucip olmiyan yani kanuna karşı yapılan hileler bu maddenin şümulüne giremez.

Fakat vaziyet Isviçre Medenî hukuk bakımından tetkik edilirse ayni noktai nazarı ileri sürmek imkânı yoktur. Zira, Isviçre Medeni $\mathrm{K}$. nun 2 inci maddesinin 2 inci fıkrasına göre bir hakkın açıktan açığa suiistimalini kanun himaye etmez «L'abus manifeste d'un droit n'est pas protégé par la loì.

Görülüyor ki, Isviçre Medenî $\mathrm{K}$. nun hakkın suiistimaline dair dan hükmü Türk Medenî $\mathbf{K}$, nun bu hususa taallûk eden hükmüne nazaran daha geniştir.

Isviçre mahkeme içtihatlarına göre hakkın suiistimali mefhumu hüsnü niyet kaidelerine muhalif hareketlerde tezahür etmekte ve o sahada toplanmaktadır. Binaenaleyh, Isviçre hukuku bakımından hakkın suiistimali ile kanuna karşı hile arasında bariz bir fark görmenin imkânı yoktur. Nitekim, federal mahkeme, hakkın suiistimali prensibine dayanarak, biraz sonra kısaca temas edeceğimiz calî evlenmeleri «marıages fictifsos hükümsüz addetmiştir.

\section{\$ 5-Kanuna karş bilenin tatbiki:}

1 - Bunlarin başında ecnebi memleketlerde çok tesadüf edilen câli evlenmelerden «mariages fictifs» bahseylemek lâzımdır.

Câli evlenmeden maksat, evlilik bağının doğutduğu kanuni neticelerden bir çoklarına tarafların riayet etmek istemiyerek yani bu neticeleri ne arzu ne de kabul ederek akdettikleri evlenmelerdir [ $\left.{ }^{6}\right]$.

Câli evlenme ile bir kadınin ya bir paye veya bir isim, ya bir tabiiyet iktisap etmesini yahutta bir kanun hükümden istifade veya idari mahiyette bir tedbirden kurtulmasinı 'temin veya nesebi sahih olmiyan bir çocuğun nesebinin tashihi için aktedildiğine tesadüf edilir [ $\left[{ }^{\top}\right]$.

[*] A. Richard, cali evlenmeler, ceviren ve not edea Ferit Idudk 'Saymen, S. 482.

[?] Richand, adr gecen eser, S. 482. 
Câli evlenmelerin iptali mahkemelerden talep olunabilir mi? Acaba gayesinin veya mevzuunun ahlâka mugayir olması sebebiyle bu gibi evlenmeler borçlar kanununun 20 nci maddesi hükmüne tevfikan bâtul addedilebilir mi?

Federal mahkeme bu hal suretini kabul etmemiştir. Evlenmeyi alelâde bir mukaveleden tefrik ve bu itibarla onu borçlar $K$. nun düsturlarına doğrudan doğruya tâbi kilmanın imkânsızlığını kabul etmek lâzımdır $\left[^{8}\right]$.

Tarafların iradesi noktasından evlenmede akdî bir mahiyet görülebilirse de, bunun bir âmme hukuku müessesesi olduğu da vârittir. Evlen menin infisahı sebepleri munhasızan devletin koyduğu kaidelere tâbidit. Bu müessesenin butlan sebeplerini kanun tahdidi «limitatif» olarak vazetmiştir. Binaenaleyh, hâkim diğer butlan sebeplerini, kıyasen evlenmenin butlant için tatbik edemez.

Câli evlenmelerin muvazaalı olduğu vârit olabilir mi? Federal mahkeme câli evlenmelerde muvazaayı kabul etmiyor. Fakat bu noktai nazar bütün Isviçre müellifleri tarafından kabule mazhar olamamıştır. Filhakika Friburg Úniversitesi Hukuk Fakültesi Medenî Hukuk Profesörlerinden «Sigwart» câli evlenmelerde muvazaa mevzuubahis olabileceğini iddia 'etmektedir. Profesör Richard pek haklı olarak bu fikre iştirâk etmiyor. Ve diyor ki: Devlet mümessili, nişanlıların evlenme ile bağlı bulunduklanın kanun namina beyan ediyor. Bu memurun rolü meselâ bir mukavele hükümlerini kaleme alan noterin roliyle kryas edilemez. Evlendirme memuru evlenme müessesesine bir âmme hukuku inşai tasarrufu «acte formateur de droit public» mahiyeti vermek için müdahale eder. Âmme hukuku inşai tasarrufu telâkkisiyle muvazaa iddiası vârit değildir [ $\left[^{0}\right]$.

Evlenme aktinde muvazaa iddiası dermeyan edilemez. Kanun vâzı evlenmedeki butları sebeplerini tahdidi bir şekilde tesbit etmiştix.

Câli bir evlenme hakkın suiistimali prensipine istinaden hükümsüz addedilebilir mi?

Federal mahkeme, son bir kararında câli bir evlenmeyi hakku suiistimali esasına istinat ederek bâtıl addetmiştir. Nöşatel Hukuk Fakültesi Medenî Hukuk Profesörlerinden Charles Knapp, Federal mahkęme-

[8] Richard, adi geçen eser, S. 489.

['] Richard, aynj eser, S. 491. 
nin bu kararını tenkid eylemektedir $\left.\mathbf{[}^{10}\right]$. Çünkü evlenmek kanunsuz butlan olamaz.

Buraya kadar verdig̈imiz izahat bize gösteriyor ki, mevzuu hukuk «de lege lata» bakimindan câli evlenmelerin hükümsüz addedilmesine imkân yoktur.

Kanun vaz'ı «de lege ferenda» noktasından birtakım yenilikler yapilmak icabetmektedir.

Richard'a göre câli evlenmelerden doğacak tehlikeyi bertaraf etmek için iki kanunu hükmün değiştirilmesi düşünülebilir:

a - Karıyı kocasının tâbiiyetine getiren hüküm;

b - Evlenmenin butlanr sebeplerini sayan hüküm;

c - Tâbiiyetin iktisabının butlanı:

Münhasıran kocasının vatandaşlığını iktisap gayesini güderek bir Isviçreli ile evlenen kadının iktisabettiği bu vatandaşlıktan iskatını derpiş eden hükmün, Richard'a göre ya medenî kanuna veya federal vatandaşlık kanununa ilâvesi lâzımdır. Bu suretle evlilik baki kalryor; fakat hükümlerinden biri olan tâbiiyeti iktisabı ortadan kaldırılmış oluyor.

Federal hükümetin bu hususta bir kararından bahsetmek yerinde olur. 20/2 nci Kânun/940 tarihli olan bu karara göre Isviçre tâbiiyetinin iktisap ve ziyauna dair hükümler değiştirilmektedir. Buna göre telsik ve evlenme ile tâbiiyet iktisabt iptal edebilir.

29/Haziran/1938 tárihli ecnebilerin Türkiyede ikamet ve seyahatları hakkındaki kanunun' 25 inci maddesine bir hüküm koyan Türk kanun vâzıı tâbiiyet iktisabı için baş vurulan câli evlenmelere bir dereceye kadar mâni olmak istemiştir.

Bu maddeye göre «bu kanun mucibince sınır dışı edilmiş olan veya umumi hükümlere göre Türk vatandaşlığını kaybetmiş bulunan ecnebi kadınlarla sınıt dışı edilmesine veya vatandaşlıktan iskatına evlenme muamelesinin tekemmülünden evvel karar verilen ecnebi kadınlar 1312 numatalı Türk vatandaşlığı K. nun 13 üncü maddesiyle ecnebi kadınlara bahşedilen haktan istifade edemezler.

1 - Yeni bir butlan sebebi koymak:

Fikrimizce en müessir hüküm Medenî Kanunumuzun 112 nci maddesine yeni bir mutlak butlan sebebi ilâve etmekten ibaret olacaktır.

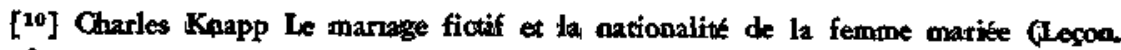
publique donné le 8 mai 1940 à l'Université de Neuchâtel) bakmz: 
Bu hüküm şöyle olabilir: Munhasıran kadına tâbiiyet tevfizi için aktedilen evlenmeler bâtıldır.

2 - Hileli telsikler «naturalisations frauduleuses»:

Boşanma kararı istihsal edebilmek için yapılan hileli telsiklerifi «naturalisation frauduleuse» misallerini Fransız devletler hususi hukukuna bir nazar atfederek vereceğiz.

Her eşyden evvel şurasını zikredelim ki, hile bazan her iki eşe kabili isnattır. Bazan da eşlerden yalnız birine isnat edilebilir. Boşanmaya müsaade eden bir ecnebi $K$. nun tatbikini temin maksadiyle kari kocanun birlikte ecnebi bir memlekette tâbiiyetlerini değiştirmeleri halinde her iki eşe kabili isnat hile mevcuttur.

Eşlerden yalnız birine kabili isnat olan hileye misâl olmak ïzere meşhur «Bauffremont-Bibesco» dâvast «affaire Bauffremont-Bibesco» zikredilebilir.

Aslen Belçikalı olan ve evlenme ile Fransız tâbiiyetini alan Prenses Bauffremont o zaman Fransız kanunu boşanmayı tecviz eylemediği cihetle (hâdise 1884 den evvel cereyan etmiştir) evvelâ ayrılık kararı alıyor. Bilâhara Sax-Altenbourg büyük dukalığinda «Le grart-duché de Saxe Altenbourg» telsik ediliyor. Bu memleket kanunundan istifade ederek ayrılığı boşanmaya tahvil ettiriyor. Ve mütaakıben Bibesco namında bir Romanyalı ile evleniyor; ve Fransaya dönïyor. Fransız olan kocası boşanmanın ve bunun neticesi olarak ikinci evlenmenin hüküm ifade etmediği hakkında dâva açyor.

Fransız Temyiz Mahkemesi müddea aleyłranın boşanmasının kanuna hile ile elde edildiği mülâhazasiyle bu muameleleri hükü̈nsüz addediyor.

Eşlerden her ikisine kabili isnat olan hileye misal olarak Vidal dâvası zikredilebilir. Bay ve Bayan Vidal 1864 evleniyorlar. 1864 de ayrılıklarına karar veriliyor. Isviçreye gidiyorlar; Şafuz «Schaffouse» kantonu tâbiiyetini iktisabediyorlar. Ayrıltkları boșanmaya inkılâp ediyor. Bayan Vidal biraz sonra evleniyor; ve ayai mesele ortaya çkıyor. Fransız Temyiz Mahkemesi boşanmanın hüküm ifade etmediğine karar veriyor.

3 - Akitlerin şekilleri:

Bircakım hukuki muameleleri âdi senetle yapmayı meneden bir memleket tâbiiyetini haiz olan şahısłar, başka bir memlekete giderek orada tâbi oldukları memleketin âkitler hakkında koyduğu eşkâlden ve 
masraflardan kurtulmak çaresini buluyorlar. Hibe resmî senetiè yapıllan Fransadan buna bir misal getirebiliriz. Şöyleki: İki Fransız bundan kurtulmak için Isviçreye gidiyorlar. Ve orada menkuI mallarını hiçbir şekle tâbi olmadan hibe ediyorlar. Eğer bu bir yer değiştirme hile ile olmuş ise hibenin hüküm ifade etmemesi icabeder. Çünkü; «Locus Regit Actum» kaidesi ecnebi memleketlerde bulunan vatandaşların bulundukları memleket kanunlarının emrettiği şekle uyarak her hangi bir muameleyi yapabilmeleri için ihdas edilmiştir. Yoksa, bu kaide birtakım şahısların kanun tarafından menedilmiş bir şeyi yapmaları için düşünülmüş̧ değildir.

4 - Mukavelelerin esasına taallûkk eden kaideler:

Bir mukavelede taraf olanlar, mukavelelerinden doğacak ihtilâfların halli için bir ecnebi kanununu salâhiyettar kılabilirler. Bu, devletler hususi hukukunda iradenin muhtariyeti «autonomie de la volonté» prensipinin tabiî bir neticesidir. Fakat, bazan âkit tarafları mukavelelerinden çıkacak ihtilâfları halledecek kanunu sarahatle göstermezler. Bunun için bazı karinelere «Présomptions» müracaat etmek lâzım gelir. Fransada bu takdirde mukaveleyi idare edecek olan kanun, taraflar aynı tâbiiyette değilseler mukavelenin in'ikat ettiği yer kanunu, yani «Lex Loci Contractusos dir.

Şu halde, bir Fransız Fransada kabul edilmiyen tahkim şartını mukavelesine koymak için bu şartın kabul edildiği memlekete gitse ve bu şara mukavelesine dercettirse bu muteber değildir. Çünkü, bu Fransızın yer değiştirmesi hile ile olmuşstur.

\section{$\S 6$ - Kanuna kaŗ̧ bile nazariyesinin bükümleri:}

Kanuna karş̧ hilenin hüküm ve neticelerini üç kısımda tetkik etmek doğru olur.

1 - Hileye uğrayan memleket «pays fraudês hakkında:

Bazı mahkemeler yapılan telsiklerin keenlemyekün olduğu ve alâkadarların eski tâbiiyetlerini muhafaza eylediklerini kararlaştırmı̧̧lardır. Fransız Temyiz Mahkemesi bu tezi kabul etmiyor. Fransız Temyiz Mahkemesinin içtihadına göre telsik bir ecnebi memleket hükümeti tarafından bahşedilmiştir. Bir Fransız mahkemesinin bu telsikin ecnebi kanun nazarında muteber olmadığını beyana hakkı yoktur. Fransız mahkemesinin yapacağı iş ancak şudur: Bu telsikten elde edilecek neticeleri hüküimsüz addetmek. Prenses. Bauffrenont Alman olmayı arzu etmişti. Prensesin ecnebi bir memlekette tâbiiyetini değiştirmesi meselesi Fransız kanununu ihlâl eden bir mesele değildir. Prenses boşanmak suretiyle Fransız kanununu ihlâl etmek istemiştir. $O$ halde yalnız boşanması hüküm ifade etmez. Ve ikinci evlenme de tabiatiyle bâtıldır. 
2 - Tarafların hâkimiyeti altına girdikleri kanunun cari olduğu memlekete göre:

Bu memleketlerde mahkemeler, taraflarin yeni kanundan tamamen istifade etmeleri lâzım geldiğine karar vermişlerdir.

Bartin'nin ileri sürdüğ̈̈ sisteme göre bu hal sureti yerindedir. Çünkii, bu sisteme göre kanuna karşı hile âmme intizamının tatbikı halinden başka bir şey olmadığına nazaran mevzuubahis devletin âmme intizamı nasıl ihlall edilmiş olabilir? Zira bu memleket kanunu dermeyan edilmektedir.

Niboyet'in pek haklı olarak tebarüz ettirdiği gibi, âmme intizamı fikrinden başka bir fikirden, ve meselâ âmir hükümlerin müeyyidesi prensipinden hareket edildiği takdirde hile ile bertaraf edilen ve beynelmilel bakımdan salâhiyetli olan bir kanuna göre muameleyi hükümsüz addetmek icabeder $\left[{ }^{11}\right]$.

Fransiz mahkemeleti, mesele Fransada bahis mevzuu olduğu ve Fransiz kanunundan istifade edildiği takdirde bu meseleyi, kanuna karşı hile nazariyesini göz önünde tutmadan, Fransız kanununu tatbik suretiyle halletmisslerdir. Ferrari dâyasında verilen karar buna bir misal teşkil edebilir Zahiren, Ferrai dâvasında verilen karar, Bauffrémont dâvasında verilen karara tezat teşkil etmektedir. Halbuki, mesele iyice tetkik edilirse vaziyetin böyle olmadığı kendiliğinden meydana çıkar.

Filhakika, Italyan tâbiiyetinde olan bayan Ferrai Fransız tâbiiyetini iktisabetmiş ve Fransada boşanma talebeylemiştir. Kocası Bay Ferrai, Italyan tâbiiyetini muhafaza ediyordu. Bu, Bauffremont vaziyetinin tamamiyle aksidir.

Fransız Temyiz Mahkemesi Bayan Ferrai, Fransız tâbiiyetini surf boşanabilmek için aldığı halde, boşanmayı hüküm verebilmesini pek tabiî bulmuştur.

Hiç şüphe yokki, hile âmme intizamna sokulduğu takdirde Franstz Temyiz Mahkemesinin kabul eylediği hal sureti pek yerinde ve doğrudur. Fakat, hile mefhumu âmir kanunların müeyyidesi şeklinde kabul edildiği takdirde bu hal sureti doğru olamaz $\left[{ }^{12}\right]$.

3 - Úçüncüsü memleketler hakkında:

Ǔçüncü memleketlerde kanuna hile müeyyidesi daima ona verilen vasfa tâbi olacaktur. Şöyleki:

a - Fğer, hile âmme intizamuna giren bir mefhum olarak kabul ediliyorsa, üçüncü memleket mevzuubahis olan kanunlardan kendi âm. me intizamına taallûk edenleri kabul edecektir.

[11] Niboyete, adt geçen eser, 589.

[12] Niboyet, adr gecent eser, $P$. 
Eğer, meselâ bayan Ferrari boşanmış bir kadın vasfını boşanmayı kabul etmiyen bir memlekette dermeyan edecek olursa, bu memleket hâkimi bunu kabul etmiyebilir. Bilâkis boşanmayı kabul eden bir memlekette dermeyan ederse bu memleket hâkimi bunu kabul edecektir. Görüliüyor ki, vaziyet üçüncü memleketin âmme intizamına tâbidir.

b - Eğer, hile mefhumu âmir kanunların müeyyidesi fikrine tâbi kılınırsa vaziyet tamamen başkadir. Üçüncii memleket hâkimi ihlâl edilmiş olan âmir kanuna riayet etmek mecburiyetindedir. Çünkü, bu kanun salâhiyetli olan bir kanundur. Ve bu itibarla tatbiki icabeder.

$\$ 7-$ Yabanct memleketler mevzuat, jurisprudans ve doktrininde kanuna karşı bile:

Almanyada: Devletler hususi hukuku bakımından kanuna karşı hile, kanun metinleriyle derpiş edilmediği gibi, müeyyideye bağlanma imkânı da doktrinin büyük ekseriyeti tarafından reddedilmiş bulunmaktadır. Kohler, Endeman ve Pfaff gibi tanınmış müellifler, muhalif fikri müdafaa etmişlerdir $\left[{ }^{13}\right]$.

Mahkeme içtihatlanna gelince: bu hususta Oldenbourg mahkemesi tarafından halledilen bìt ihtilâf zikredilebilir. Bu, Mahallî K. nun merasiminden daha liberal olan Brem serbest şehrine giderek orada vasiyet eden bir Oldenburglunun vasiyetinin iptaline taallûk eden bir talepti. Kanuna karşı hile mevcut olduğu halde mahkeme talebi reddetmiştir [ [14].

Arjantin: 1888 Tarihli Arjantin Medenî K. nun 159 uncu maddesi, evlenmeyi, evlenme akdinin yapıldığı yer kanununa «Lex loci celebrationisos tâbi kılmaktadır. Bu maddeye göre müstakbel kar1 koca Arjantinde meriyette bulunan kanun hükümlerinden kurtulmak maksadiyle, ikametgâhlarını terketmiş olsalar bile vaziyet bu merkezdedir.

Görülüyor ki, Arjantin kanuna karşı yapılan hileyi nazarı dikkate almamı̣ş, hile ile yapılan muameleri muteber addetmiş olmakla devletler hususi hukukunda hileyi tanımıan doktrini kabul eylemiştir $\left[{ }^{15}\right]$.

Belçika: Belçika devletler hususi hukuku müellifleri kanuna karşı hile kullantlarak yapılan muamelelerin hükümsüz addedilip edilmemesi noktasında ittifak etmiş değildirler. Belçika mahkeme içtihatlarında, tional VII.

$\left[{ }^{13}\right]$ Bak: Droit international privé de P'Allemagne, néperpoire de droit interna-

[14] Bak: Rlépertoire de droit intenaational, T. Vzill. P. 476.

[15] Bak: Droit interenational privé de l'Argentine, Répertọire de droit international VI. 
Fransada olduğu gibi hileli muamelelerin muteber olmadiğı hususunda kuvvetli bir temayül kendini göstermektedir $\left[{ }^{16}\right]$.

Şili: Şili kanunu Şili tâbiiyetini haiz olan şahısların yabancı memleketlerde, millî kanunlarının hükümleerini bertaraf etmek için yaptrkları evlenme akitlerini bâtıl addeylemekte, bu sutetle devletler hususi hukukunda kanuna karşı hileyi tanimaktadır.

Italya: Kanuna karşı hile «Frode alla legge» meselesi Italyan doktrinin nazarı dikketini celbetmiş bulunmaktadır. Bu mesele etrafında birçok eserler neşredildiği gibi, makalelerde yazılmışır.

Surasını kaydetmeliyiz ki, Italyan kanunlarına karşı yapılan hilelere devletler hususi hukukunda çok tesadüf edilmekte, hile bilhassa Italyan tâbiiyetinde olan şahısların yabancı memleketlerde boşanmala. rinda tezahïr etmektedir.

Yukarda da söylediğimiz veçhile, Italya hukuk mevzuatı boşanmayı meneylemekte olduğundan bu yasaktan kurtulmak için birçok tâbiiyet değişmelerine şahit olunmaktadır.

Hilenin bu nevi Italyada uzun zamanlardan beri tanınmaktadır. Hassaten birinci cihan harbinden sonra Fiume şehrinin serbest bir şehir haline geldiği 1924 Tarihinden bu şehrin Italyaya ilhak edildiği zamana kadar bu şekilde hilenin baş vurulduğu çok görülmüş̧ür. Fiume şehri ecnebilere çok kolaylıkla kendi tâbïyetini bahşettiğinden ve boşanma müessesesini kabul eylediğinden birçok Italyanlar boşanmak ve sonra yeniden evlenebilmek maksadiyle Fiumeye geliyorlardı $\left[{ }^{17}\right]$.

Italyan mehkemeleri bu kabil hileli boşanmalar münasebetiyle biribirine zit kararlar vermişlerdir. Mahkeme içtihatlarında esasen birlik teessüs etmesi de imkânsızdr. Çünkü, son zamanlara kadar Italyada mütaaddit Temyiz Mahkemesi mevcuttu. «Roma T'emyiz Mahkemesi, Torino Temyiz Mahkemesi, Napoli Temyiz Mahkemesis bumunla beraber bu gibi boşanmaların muteberiyetine dair açık bir temayül kendini göstermiştir. Bundan dolayıdır ki, Italyan Hükümeti, idari tedbirlerle bu hale karşı harekete geçmek mecburiyetini hisseylemiş, hileyi firenlemek için Italyan tâbiiyetini, boşanabilmek için terkeyleyen Italyanların, yeniden Italyan tâbiiyetine girmek hususundaki taleplerinin reddedilmesine karat vermiştir.

Italyan doktrini de umumiyetle hileli boşanmaların idamesi lehindedir.

[16] Bak: Droit international priae de la Belgique, Répertoire de droit international T.VI

[1i] Bu thususta daha fazla tafsilât için bak: R Rgis Revol, les divorces de Fiưne, futhis, Aix, 1925. 
Italyan hukukunda kanuna karşı hilenin tatbikatından olmak üzere 1867 Tarihli Lucques mahkemesinin bir kararr zikredilebilir. Bu karar; Italyan K. nun, koyduğu formaliteleri bertaraf etmek maksadiyle ecnebi bir memlekette yaprlan vasiyetnameyi hükümsïz addetmiştir $\left[{ }^{18}\right]$.

Isviçre: Isviçre devletler hususi hukukuna mütaallik hükümleri ihtiva eden 25/Haziran/1891 Tarihli federal kanun $\left[{ }^{10}\right]$ kanuna karş1 hile hakkında hiçbir hüküm ihtiva eylememektedir. Áncak, bu kanunu itmam eden Isviçre Medenî $K$. nun son babında bu hususa dair bir hükme tesadüf eylemekteyiz. Bu hüküm evlenme aktine taallûk etmektedir.

Filhakika son babin59 uncu maddesinin 7 fıkrasına göre ecnebi bir memlekette orada mer'î kanunlar mucibince akdedilen evlenmelerin muteberiyetini Isviçre tanımaktadır. Iş̧bu hükme göre Isviçre tabaasının yabancı memleketlerde akdeylemiş oldukları evlenme dinî bir memur huzurunda olsun veya diplomatik mahiyette bulunsun hiç kiymeti yoktur. Yeter ki evlenme, aktin yapildığ memleket kanunu «Loi du pays de la célébrátion» nazarında muteber bulunsun. Fakat, aynı fikraya göre müstakbel karı koca $\left[^{20}\right]$ Ísviçre Medenî $\mathrm{K}$. nun irae ettiği butlan sebeplerini bertaraf etmek niyetiyle ecnebi memlekette evlenme akti yaptıklanı takdirde bu akit Isviçrede tanınmıyacaktır $\left[{ }^{21}\right]$.

Japonya: Japon Medenî K nun 10 uncu maddesi, Locus Regit Actum kaidesini ihlâl etmek için, yani bu kanunun tesbit eylediği formaliteyi bertaraf eylemek niyetiyle yabancı memleketlerde aktedilen mukaveleleri Japon kanununa tâbi kılmıştır. Görüllüyor ki, Japon K. nun formalitelerinden kurtulmak niyetiyle ecnebi memleketlere gidilmezse bu memleketlerde Japon $\mathbf{K}$. nun koymuş olduğu şekiller haricinde yapılacak olan muameleler muteber olacaktır. Şu izahat bize gösteriyor ki, Japonya, kanuna karşı hile kullanılarak yapılan muameleleri hükümsüzz addeylemektedir $\left.{ }^{22}\right]$.

Romanya: Romanya mevzuatında kanuna karşı hile hakkında bir hükme tesadüf edemiyoruz. Fakat Romanya mahkeme içtihadı hile ile yapılan muameleleti hükümsüz addeylememektedir. Filhakika, Romanya

[18] Bak: Revue de droit intemational 18751 P. 208.

[19] Loi fídiérale sur les rapports de droit civil des citongus ou en $=$ séjour. ayoudtr.

[20] Müsealkbel karı koce, İsviçrede ikamet eden Isviçreli veya yabancr olsun hüküm

[21] 7. F, aynen söyledir: La validitớ d'un matiage oélábré a l'étranger conformémen aux lois qui y sont on vigueur est reconnue en Suisse, à moins que = les parties oll'aient concula à l'ketranger l'intemation maniceste d'éluder Jes causes de unullité prévues par la loi suissés

[22] Bak: Droit intenational privé du japon tépertoine de ḋoit intemational VI. 
Temyiz Mahkemesi, 1921 Tarihinde vermiş olduğu bir kararında kanuni şekilleri bertaraf etmek maksadiyle yabancı memleketlerde yapılmış olan evlenmeyi mutebr addetmiştir $\left[{ }^{23}\right]$.

Rusya: Kanuna karş̣ hile meselesi ne inkulâptan evvelki Rus doktrininde ne de mahkeme içtihatlarında tetkik edilmemiştir. Yeni doktrinde Krylov kanuna hileyi âmme intizami «Ordre public» tahdidinin tatbıkından başka bir şey addetmemektedir.

Gojchbarg ise kanuna karşı hileye taraftar görünmekte ve bunu bakkın suiistimaline sokmaktadır. Makarov da Krylov gibi kanuna karşı hileyi âmme intizamına ithal eylemektedir $\left[{ }^{24}\right]$.

Ingiltere ve Birleşik Amerika: devletler hususi hukukunda kanuna karşı hilenin mukayeseli hukuk bakımından tetkikinı bitirmeden evvel Ingiltere ve Amerikada vaziyetin neden ibaret olduğunu da gözden Geçirmeliyiz.

Bilindiği gibi, Ingilterede ve birleşik Amerikada ahvali şahsiyeye «statut personnel» ikametgâh kanunu «Lex domicilii» tatbik edilmektedir. Bu kanunun tatbik edilmesi, ve ikametgâhın değişmesi de kolay olduğundan kanuna karşı hileye bu memleketlerde daha çok tesadüf edilmektedir.

Birleşik Amerikada, kanuna karşı hile ile yapılan muameleler hükümsïz addedilmekte, yani bu nazariye göz önünde tutulmakta ise de, Ingilterede doktrin ve mahkeme içtihatlan bunu nazarı itibara almamakta, ve hile ile yapilan muameleleri muteber addetmektedir. Bu hususta Î́skoçyadan bir misal getirebiliriz: Iskoçyada evlenme hiçbir şekle tâbi olmadiğı cihetle birçok Ingilizler kolayca evlenebilmek maksadiyle Iskoçyaya gidiyorlar, orada ikametgâh tesis ederek evlenme akitlerini yaptıktan sonta Ingilttereye dönüyorlar. Ingiliz mahkeme içcihatları, ikametgâh tesisi hile ile olduğu halde, bu gibi evlenmeleri muteber tutmaktadir.

Netice: Devletler hususi hukukunda kanuna karşı hileye yer vermek lâzım gelir kanaatindeyiz. Aksi takdirde devletler hususi hukuku suiistimal edilmis olur. Tarafların Devletler hususi hukukunun prensiplerini oyuncak haline getirmelerine asla müsaade edilmemelidir. Bununla betaber itiraf etmeliyiz ki, bu nazariyenin kabuliyle hâkim çok müşkil

$\left[{ }^{23}\right]$ Droit international privé de la Roumanie, Répertoite de droit intennational T. VIr

[24] Makarov, Pnécis de droìt intenational privé d'apnés la législation et la doctrine russes, $P .152$. 
vaziyette bırakılmış olacaktır. Fakat inkâr edilmezki, dahilì hukukta suiniyetle yapılan muameleleri, hüsnüniyetle yapılan muamelelerden ayırmak mecburiyetinde olan hâkim, daha az müşül olan bir vaziyet içind: değildir. Hâkim, bu hususta takdir hakkını kullanarak hileye müracaat suretiyle yapilan muameleleri baltalamal, Devletler hususi hukukunun sviistimal edilmesine meydan vermemelidir. Ancak bu suretledir ki, suiníyetle yapilan muameleler, hüsnüniyetle yapilan muameleler derecesine çıkarılmamış olur.

Dog̣ent Dr. Osman Fazal BERKंI 